\title{
Extract of Ellagitannins starting with Strawberries (Fragaria sp.) and Blackberries (Rubus sp.)
}

\author{
Anahí MÁRQUEZ-LÓPEZ1, Fernando AYALA-FLORES², Stolishnaya MACÍAS-PURECO², \\ Ma. del Carmen CHÁVEZ-PARGA ${ }^{1}$, Dora Cecilia VALENCIA FLORES ${ }^{2}$, Rafael MAYA-YESCAS ${ }^{1}$, \\ Juan Carlos GONZÁLEZ-HERNÁNDEZ2* (D)
}

\begin{abstract}
Characterize the content of phytochemical compounds present in samples of extracts of strawberry (Fragaria sp.) and blackberry (Rubus sp.). The extraction of said compounds was carried out with solutions of polar solvents, such as acetone, ethanol and methanol, using an experimental design with three factors: state of maturity, resting time and temperature. The characterization of these fruits is the beginning of the utilization mainly of ellagitannins to produce ellagic acid. Total phytochemical content was determined by spectrophotometric techniques, for phenolic content it was used Folin-Ciocalteu, for flavonoids it was determined with aluminium chloride, the antioxidant activity was evaluated by the methods of DPPH and ABTS ${ }^{+}$, the bactericidal effect of the extracts was shown for strains of $E$. coli and S. aureus. The determination of ellagitannins was performed by spectrometry. The influence of the state of maturity on the response variable was evaluated; it was observed that concentration of phytochemicals increases proportionally to maturity stage. The antioxidant activity was evaluated, determining that extracts obtained exhibit $94 \%$ - 95\% inhibition. The determination of ellagitannins, finding that the highest concentration of ellagitannins was found in a state of green maturity, for strawberries as well as blackberries.
\end{abstract}

Keywords: ellagitannins; strawberries; blackberries; phytochemicals.

Practical application: Phytochemical characterization of strawberry and blackberry endemic to the state of Michoacán, highlighting the obtaining of ellagitannins for use in processes of obtaining ellagic acid.

\section{Introduction}

Polyphenols are a large group of substances with different chemical structures and activities, which are important constituents of plants and give them many beneficial effects. Especially these components can exert antioxidant effect, such as the sequestration of free radicals, donating hydrogen molecules, clearing of superoxide molecules, chelating transition metals. These properties are attributed mainly to the hydroxyl group present in its structural ring; tannins are distributed in roots, stems, bark, trunk, leaves, flowers, fruits and seeds. Tannins are soluble in water, exhibit high molecular weights from $500 \mathrm{Da}$ to $3000 \mathrm{Da}$, and possess sufficient hydroxyl groups attached to phenolic structures that confer them the characteristic of forming complexes with proteins, minerals and other macromolecules. There exist two groups of tannins: condensed and hydrolysable tannins, hydrolysable tannins, such as gallotannins or ellagitannins, come from the esterification of non-flavonoid polyphenolic compounds, such as gallic or ellagic acid, respectively (Vázquez-Flores et al., 2012).

Ellagitannins are a large group of polyphenolic compounds widely distributed in plants (Seeram et al., 2005), their structure exhibit great variability since there are multiple places where the unit of ellagic acid can be linked with the glucose molecule (Batra \& Saxena, 2005). The study, application and interest in obtaining these compounds lies in the therapeutic effects that are primary in its hydrolysed form, ellagic acid (Huang et al., 2008), which has many important applications, such as antioxidant, antimicrobial, antiviral and antitumor (Seeram et al., 2005). However, the application of ellagic acid has not been exploited due to its high cost of production, both with chemical methods using acid hydrolysis, as well as with biotechnological processes, using high cost enzymes and vegetable matter to extract the scarcely available ellagitannins in the region.

In this work, the study of strawberries and blackberries, endemic to the State of Michoacán, was carried out. These two berries are among the fruits with the highest levels of antioxidants, adjudged to the content of vitamin C, anthocyanins and ellagitannins. Additionally, the anthocyanins, which are pigments that give red or purple colour to fruits, have been attributed benefits against coronary heart disease and certain types of cancer (Middleton et al., 2000). Considering these aspects, we can conclude that strawberries and blackberries function as a source of potentially healthy phytochemical compounds.

${ }^{1}$ División de Estudios de Posgrado de la Facultad de Ingeniería Química, Universidad Michoacana de San Nicolás de Hidalgo, Ciudad Universitaria, Morelia, Michoacán, México

${ }^{2}$ Tecnológico Nacional de México, Instituto Tecnológico de Morelia, Colonia Lomas de Santiaguito, Morelia, Michoacán, México

*Corresponding author: jcgonzal@itmorelia.edu.mx 


\section{Material and methods}

\subsection{Raw material}

Strawberries Aroma variety and blackberries Tupi variety were used for the development of the project; raw fruits were obtained in the community of Los Reyes, Michoacán. The strawberries and blackberries used did not present physical defects, it was considered to have an adequate firmness, as well as a colour according to the state of maturity

\subsection{Determination of the state of maturity}

The guidelines established by the NMX-F-102-S-1978 were followed: $10 \mathrm{~g}$ of the sample were placed in $27 \mathrm{~mL}$ of distilled water and filtered with filter paper, then gauged to $75 \mathrm{~mL}$ in a flask with distilled water. This sample was titrated in triplicate with $0.1 \mathrm{~N} \mathrm{NaOH}$, number of equivalent acids (acetic, citric, tartaric, malic, oxalic and lactic) was determined.

\subsection{Extraction of the phytochemicals}

The methodology proposed by Huang et al. (2008), was taken and modified. $10 \mathrm{~g}$ of fresh raw material was weighed and grinded in an Oster ${ }^{\circledR}$ blender using $100 \mathrm{~mL}$ of solvent, (acetone, ethanol and methanol), allowed to stand according to conditions proposed in the design of experiments, and subsequently distilled using the Heidolph ${ }^{\circledR}$ rotary evaporator Hei-VAP advantage series.

\subsection{Design of experiments and extraction conditions}

A factorial design of experiments $2^{3}$ was established and implemented, with three replicates in the central point, using as factors the temperature $-18^{\circ} \mathrm{C}$ to $-3{ }^{\circ} \mathrm{C}$, resting time $24 \mathrm{~h}$ to $48 \mathrm{~h}$ and state of maturity, previously determined, classified from green to over-mature. The commercial software program Statgraphics ${ }^{\circledR}$ was used for the statistical analysis.

\subsection{Total phenolic content}

The total content of phenols was performed spectrophotometrically described Fonseca-García et al. (2014), $5 \mathrm{~mL}$ of fruit extract was mixed with $45 \mathrm{~mL}$ of the solvent used, $1500 \mathrm{~mL}$ of distilled water, $500 \mathrm{~mL}$ of Folin-Ciocalteu reagent, manually stirred and left to react for $15 \mathrm{~min}$. Afterwards reaction was stopped using $20 \%$ sodium carbonate (w/v) and allowed to stand for one hour, and then read in the Perkin Elmer 35 UV-Visible spectrophotometer 35 at $625 \mathrm{~nm}$.

\subsection{Total flavonoid content}

The flavonoid content was determined by modification of the essay reported by Liu et al. (2011). $200 \mathrm{~mL}$ of fruit extract were mixed with $50 \mathrm{~mL}$ of aluminium chloride, allowing to react for $5 \mathrm{~min}$. Reaction was stopped supplying $50 \mathrm{~mL}$ of sodium acetate and subsequently $2300 \mathrm{~mL}$ of the solvent used was added and was measured in the Perkin Elmer Lambda 35 UV-Visible spectrophotometer at $475 \mathrm{~nm}$.

\subsection{Determinations of antioxidant capacity}

The determinations were made according to the methodology proposed by Brand-Williams et al. (1995), with some modifications: For the determination with $\mathrm{ABTS}^{+}$radical, the Perkin Elmer Lambda 35 spectrophotometer was calibrated at $734 \mathrm{~nm}$ with ethanol, the absorbance of the $\mathrm{ABTS}^{+}$was adjusted by diluting the stock solution of Trolox with ethanol until obtaining absorbance between $0.70 \pm 0.02$ at $734 \mathrm{~nm} .990 \mathrm{~mL}$ of this adjusted solution were mixed with $10 \mathrm{~mL}$ of extract sample. The mixtures could stand for $5 \mathrm{~min}$ and the absorbance is measured in the Perkin Elmer Lambda $35 \mathrm{UV}$-Visible spectrophotometer at $734 \mathrm{~nm}$.

For quantification of the antioxidant capacity with DPPH radical, the PerkinElmer Lambda 35 UV-Visible spectrophotometer was calibrated at $515 \mathrm{~nm}$ with methanol, the DPPH absorbance was adjusted between 0.8 and 1 at the same wavelength. To adjust the absorbency, methanol or DPPH was added depending on the case. Subsequently, $2900 \mu \mathrm{L}$ of DPPH and $100 \mu \mathrm{L}$ of the sample were added to each test tube and manually stirred. It was let to repose for $30 \mathrm{~min}$ in a dark place. The absorbance was measured by the Perkin Elmer Lambda 35 UV-Visible spectrophotometer at $515 \mathrm{~nm}$.

\subsection{Total content of ellagitannins}

Total content of ellagitannins was quantified following the method proposed by Wilson \& Hagerman (1990) and Lei et al. (2001): $10 \mathrm{mg}$ of dried sample was weighed, 1,0 mL of sulfuric acid $\left(\mathrm{H}_{2} \mathrm{SO}_{4}, 2 \mathrm{~N}\right)$ was added, heated to $70{ }^{\circ} \mathrm{C}$ for $30 \mathrm{~h}$, filtered with filter paper and 9,0 $\mathrm{mL}$ of pyridine was added, $1 \mathrm{~mL}$ of the dissolutions were taken and transferred to test tubes where $1.1 \mathrm{~mL}$ of pyridine was added and then taken to an ice bath, 0.1 $\mathrm{mL}$ of concentrated hydrochloric acid was added and incubated in a water bath at $30^{\circ} \mathrm{C}$ for $5 \mathrm{~min}$, then, $0.1 \mathrm{~mL}$ of $1 \%$ sodium nitrate was added and was measured in the Perkin Elmer Lambda $35 \mathrm{UV}$-Visible spectrophotometer at $538 \mathrm{~nm}$, incubated again in a water bath at $30^{\circ} \mathrm{C}$ for $36 \mathrm{~min}$ and read again in the spectrophotometer at the same wavelength.

\subsection{Microbicidal activity}

The material used was sterilized, Escherichia coli ATCC 25922 and Staphylococcus aureus ATCC 29213 were seeded in two Petri dishes with a Mueller Hinton medium, they were incubated for $24 \mathrm{~h}$ at $37^{\circ} \mathrm{C}$. Subsequently, suspensions of colonies in saline solution were prepared inside Falcon tubes, obtaining a suspension containing between 75 and $125 \times 108 \mathrm{CFU}$. These suspensions were read at $625 \mathrm{~nm}$ in Perkin Elmer Lambda 35 UV-Visible spectrophotometer, the absorbances were between 0.8 and 1 (NMX-BB-040-SCFI-1999). With the suspensions ready, a grass with cotton-tipped swabs was made in 10 Petri dishes with a Mueller Hinton medium, then medium-pored filter paper sensi-discs were placed to which previously was added concentrated extract, antibiotics, water, solvents, respectively, they were incubated for $48 \mathrm{~h}$ at $37^{\circ} \mathrm{C}$.

\subsection{Experimental design and statistical analysis}

By using the program Statgraphics (missing symbol) an analysis was made of the design of the experiments on two levels 
with three factors using three replicas and the central point for strawberries and blackberries, respectively. The response variables analysed were: total phenols, total flavonoids and antioxidant activity.

\section{Results and discussion}

For this investigation, the decision was made to use the fruits of strawberry and blackberry, to take advantage of their availability, since they are small fruits endemic to the State of Michoacán, which is the place where said research is carried out. Michoacán being the main producer of these small fruits, while Mexico stands at the third place as a producer of fresh strawberry and at the first of fresh blackberry to the international market. In addition, it is intended to reduce the loss of the product, since large quantities of the fruits are wasted since their shelf time is very short. It is for these reasons that the study to determine their chemical composition is important, since it will provide us with information on the secondary compounds that they have to be used in other processes, such as ellagitannins that are the precursors of ellagic acid, which are used in another part of the research as a substrate of hydrolysable enzymes to obtain ellagic acid molecules (Márquez-López et al., 2019), these ellagitannins are part of a very large section of compounds that are phenols, which together with flavonoids are of interest and can be used in other processes, therein lies the importance of its determination. Like these compounds, it is important to know their antioxidant and microbicidal capacity, which are very important capacities since they allow the decrease of free radicals or bacteria, as is the case, presenting an advantage that is essential to inform in order to know the benefits of the fruits even in fresh consumption.

Part of the whole methodological strategy, an experimental design is used to analyse delimited regions that can give near-optimal response information, which allow maximum use of the fruits, allowing to know the maximum of its chemical composition and to be certain of that compounds of interest are being identified.

During this investigation, it was not intended to obtain a correlation of the data obtained between strawberry and blackberry, the main objective is to know the composition of each of the small fruits, and evaluate which is the one that contains the largest amount of ellagitannins without neglecting the other compounds mentioned above, so they can be used in the later stages of the investigation. This was the basis of the investigation, which allowed us to decide the use of strawberry only to obtain ellagic acid (Márquez-López et al., 2019), because it has in its composition the largest amount of ellagitannins resulting in a greater amount of ellagic acid, as well as its morphology that allows the best use of the strawberry.

\subsection{Determination of the state of maturity}

The physiological maturity of the fruits is associated with changes in their chemical composition and can be used as indicators of satisfactory maturity, as is the case of titratable acidity, most fruits are particularly rich in organic acids that are usually dissolved in the vacuole of the cell, either in free form or combined as salts, esters, glycosides. Free acidity represents the organic acids present which are, as the name implies, free and measured by neutralizing juices or fruit extracts with a durable base, the $\mathrm{pH}$ increases during neutralization and titratable acidity is calculated from the amount of base necessary to reach the $\mathrm{pH}$ of the endpoint of the test; in this practice, $\mathrm{pH}=8.5$ is taken as a last point using phenolphthalein as an indicator. Under these conditions, free organic acids and only a part of the phosphoric acid and phenols are involved in the result. To report the acidity, the most abundant organic acid of the vegetable product will be considered, which varies depending on the species in question, so the result is expressed in terms of the amount of the dominant acid.

The content of free organic acids decreases as the state of maturity increases, because these acids are used as substrates in respiration for the synthesis of new components during maturation (Kays, 1997), obtained for strawberry in green stage $11.7 \pm 0.85$, mature $9.6 \pm 0.85$ and over-mature $8.5 \pm 0.71$ of citric acid, where the results obtained are expressed in mg per 100 grams of fresh strawberry. Strawberries are characterized by having sweet-acid flavours, due to the sugars and organic acids present, of which citric acid predominates, being the acid on which the expression of titratable acidity is based for this fruit.

In a study conducted by Finn et al. (2011), nine strawberry varieties were analysed, where percentages of titratable acidity were found from 0.50 to $1.63 \%$, for the green maturity stage. These results are comparable with the data obtained in this investigation, where $1.17 \%$ of titratable acidity was obtained. Martínez-Soto et al. (2008) analysed eight different varieties of strawberry which obtained results between 15.12 and $8.83 \mathrm{mg}$ of citric acid for each $100 \mathrm{~g}$ of fresh strawberry, if we compare them with the results obtained in this investigation, they are very similar.

The state of maturity for blackberries, is expressed in percentages of malic acid, the results obtained in this investigation, correspond to $10.1 \pm 0.49 \mathrm{mg}$ per 100 grams of fresh blackberry ( $1.01 \%$ of acidity) in green state, $9.6 \pm 0.42 \mathrm{mg}$ per 100 grams of fresh blackberry in mature stage (9.6\% of acidity) and to $8.4 \pm 0.35 \mathrm{mg}$ per 100 grams of fresh blackberry ( $0.84 \%$ of acidity) in the over-mature state, which was compared with the research carried out by Valencia Sullca \& Guevara Pérez (2013), found in the species of blackberry Rubus fructicosus $L$. a percentage of acidity of $0.93 \pm 0.01 \%$. In a research conducted by Andrade Esquivel et al. (2008), corroborated with different varieties of blackberry grown in Michoacán, where he corroborated with Michoacán acidity decreases with the increase in maturity, this is explained through the oxidation of malic acid to $\mathrm{CO}_{2}$ or that it can convert into citric or glutamic acid (Novoa et al., 2006).

The modification of the content of organic acids during maturation depends directly on the metabolic characteristics of the species. The modification of the content of organic acids is of immense importance at the biochemical level, since the $\mathrm{pH}$ conditions the activity of a considerable number of enzymes associated with the maturation processes, such as softening, colour, odour, among others (Kays, 1997; Novoa et al., 2006). 


\subsection{Determination of phenolic content}

The extraction of phenolic compounds is determined by the solubility of the same in the organic solvent used; this solubility is increased by the polarity of the solvent. The results were summarized in Table 1, where the three stages of maturity in which the analyses for strawberries and blackberries were made are observed.

A factorial design of experiment $2^{3}$ was performed, which includes two levels and 3 factors, with replica in the central point, which indicates that midpoints were used. The design factors or variables were: temperature with low level of $-18^{\circ} \mathrm{C}$, high level $-3{ }^{\circ} \mathrm{C}$ and midpoint of $-11^{\circ} \mathrm{C}$, state of maturity low level is green, high level overripe, and midpoint is mature, and finally the resting time with 24 hours as a low level, 48 hours high level and as an intermediate point were 36 hours. With these levels 11 runs were made, of which 3 correspond to the central point that is mature maturity, $-11^{\circ} \mathrm{C}$, and 36 hours of rest, which are the conditions of the central point that corresponds to the letter $f$ of the table. Four runs corresponded to the state of green maturity in combination with the other levels of the variables, such as $-3{ }^{\circ} \mathrm{C}$ and 48 hours of rest with the letter $\mathrm{b}$ in the table, the letter $\mathrm{c}$ corresponds to 48 hours and $-18{ }^{\circ} \mathrm{C}$, the letter $\mathrm{d} 24$ hours of rest and $-3{ }^{\circ} \mathrm{C}$, and the letter $\mathrm{d}$ corresponding to 24 hours of rest and $-18^{\circ} \mathrm{C}$. These conditions were part of the other four runs corresponding to the experimental design, now in combination with the state of overripe maturity, resulting in 11 runs, which were performed with the three solvents. The experimental design was the result of making the matrix corresponding to the representative combinations based on the high and low levels that were selected for the analysis, delimiting the analysis area, to a cubic zone that is formed by the three-dimensional axes that contain the levels of each factor, having the possibility of a more precise analysis of what would be expected to be an optimal area of study, as well as the replicas of the central point that each adds a degree of freedom to estimate the experimental error.

The solvent that extracted the most was acetone, which is associated with polar compounds, such as $\rho$-hydroxybenzoic acid and ferulic acid, followed by extraction with methanol, such as ellagic acid, among other where phenols such as $\rho$-coumaric acid and its ester derivatives can be dissolved. The content of total phenols determined for strawberries, is determined, as already mentioned by the polarity of the solvent, having greater extraction of the compounds with acetone solvent, the increase in the state of maturity and the resting time, influences the amount of phenols extracted in strawberry.

The resting time, the longer it is, allows more phenols to be extracted since the contact with the phenols will be longer, it is also observed in the graphs that having a higher maturity state results in more phenols, this could be explained based on the theory that monophenolic compounds (such as phenolic acids and phenylpropanoids) are intermediates and derivatives of the metabolic path of phenylpropanoid and shikimate. The conversion of L-phenylalanine to transcinnamic acid is the initial step of the biosynthetic path of phenylpropanoids, a reaction that is catalysed by phenylalanine monialiase (FAL), an enzyme that regulates the synthesis of phenols (Olaya Zea \& Restrepo Sánchez, 2012). This enzyme remains active during the last stages of fruit growth and early maturation, favouring the biosynthesis of these phenolic compounds (Arellano Gómez et al., 2005).

Because the temperature statistically has no influence, it was determined that the best temperature for the process is at $-18{ }^{\circ} \mathrm{C}$, since in the experiments performed it is observed that it is the temperature with the highest performance in the extraction process, besides, this temperature is suitable for the process because the lower it is, the stability of the molecules that make up the phenols will be stable, without degrading and the contact with the solvent will be more appropriate, since it will decrease the volatility of the same.

As seen in Figure 1c the relationship between the resting time and the state of maturity, produces an increase in the response, due to the contact time between the phenols and the solvent at a longer contact time, greater extraction of these and the state of maturity depends on the activation of the phenylalanineamonialiase, as mentioned above, the enzyme regulating the synthesis of phenols in mature stages of the fruit in Figure 1b, the relationship between temperature and state of maturity, the increase in the state of maturity and low temperatures favoured the process for part in Figure 1a it is shown that, at

Table 1. Content of total phenols determined in strawberry and blackberry, with the conditions based on the design of experiments obtained with the statistical program Statgraphics ${ }^{\circledR}$. The data are expressed as the mean \pm standard deviation, $\mathrm{n}=13$.

\begin{tabular}{|c|c|c|c|c|c|c|}
\hline \multirow{2}{*}{ Maturity state } & \multicolumn{3}{|c|}{ Strawberry } & \multicolumn{3}{|c|}{ Blackberry } \\
\hline & Acetone $^{\mathrm{a}}$ & Ethanol $^{\mathrm{a}}$ & Methanol $^{\mathrm{a}}$ & Acetone $^{\mathrm{a}}$ & Ethanol $^{\mathrm{a}}$ & Methanol $^{\mathrm{a}}$ \\
\hline \multirow[t]{4}{*}{ Green } & $270.32 \pm 0.04^{b}$ & $199.96 \pm 0.04^{b}$ & $275.48 \pm 0.04^{\mathrm{b}}$ & $603.16 \pm 0.04^{b}$ & $235.39 \pm 0.03^{b}$ & $256.66 \pm 0.02^{\mathrm{b}}$ \\
\hline & $602.76 \pm 0.06^{c}$ & $235.31 \pm 0.04^{c}$ & $269.07 \pm 0.03^{c}$ & $693.03 \pm 0.07^{c}$ & $194.95 \pm 0.01^{\mathrm{c}}$ & $224.54 \pm 0.01$ \\
\hline & $244.82 \pm 0.18^{\mathrm{d}}$ & $75.68 \pm 0.04^{\mathrm{d}}$ & $513.70 \pm 0.04^{\mathrm{d}}$ & $205.50 \pm 0.05^{c}$ & $173.87 \pm 0.02^{\mathrm{d}}$ & $188.81 \pm 0.03$ \\
\hline & $160.30 \pm 0.06^{\mathrm{e}}$ & $97.96 \pm 0.05^{\mathrm{e}}$ & $212.40 \pm 0.05^{\mathrm{e}}$ & $456.38 \pm 0.04^{\mathrm{e}}$ & $104.13 \pm 0.01^{\mathrm{e}}$ & $187.30 \pm 0.03$ \\
\hline \multirow[t]{4}{*}{ Overmature } & $611.03 \pm 0.07^{\mathrm{b}}$ & $318.08 \pm 0.07^{b}$ & $385.56 \pm 0.04^{b}$ & $288.30 \pm 0.07^{b}$ & $177.15 \pm 0.07^{\mathrm{b}}$ & $99.87 \pm 0.02^{\mathrm{b}}$ \\
\hline & $868.43 \pm 0.06^{c}$ & $310.61 \pm 0.06^{c}$ & $448.11 \pm 0.02^{\mathrm{c}}$ & $439.95 \pm 0.06^{c}$ & $126.18 \pm 0.07^{c}$ & $74.03 \pm 0.05$ \\
\hline & $326.98 \pm 0.02^{\mathrm{d}}$ & $164.44 \pm 0.02^{\mathrm{d}}$ & $282.64 \pm 0.03^{\mathrm{d}}$ & $252.98 \pm 0.05^{\mathrm{d}}$ & $179.43 \pm 0.07^{\mathrm{d}}$ & $114.68 \pm 0.31$ \\
\hline & $343.91 \pm 0.03^{\mathrm{e}}$ & $192.77 \pm 0.03^{\mathrm{e}}$ & $265.61 \pm 0.04^{\mathrm{e}}$ & $598.34 \pm 0.08^{\mathrm{e}}$ & $102.86 \pm 0.05^{\mathrm{e}}$ & $220.74 \pm 0.07$ \\
\hline Mature & $368.92 \pm 0.05^{\mathrm{f}}$ & $226.89 \pm 0.05^{f}$ & $361.03 \pm 0.04^{\mathrm{f}}$ & $621.22 \pm 0.06^{\mathrm{f}}$ & $248.81 \pm 0.05^{\mathrm{f}}$ & $259.24 \pm 0.02^{f}$ \\
\hline
\end{tabular}

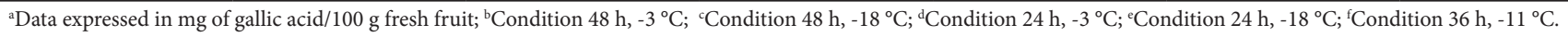




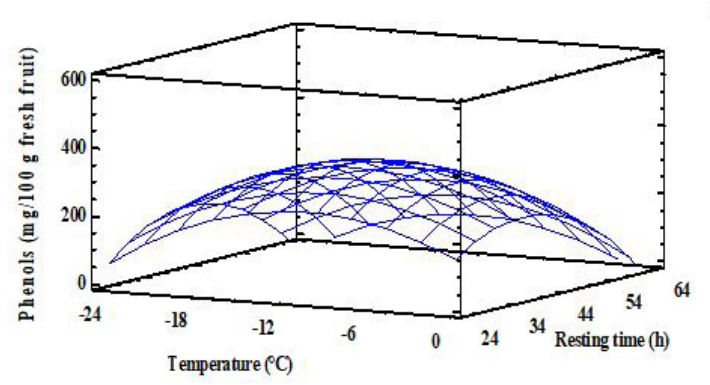

a)

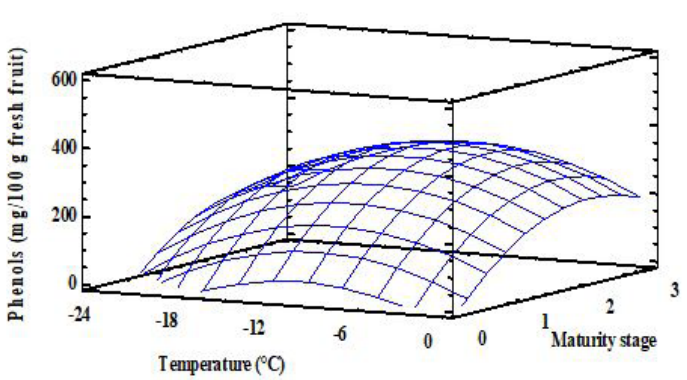

d)

c)

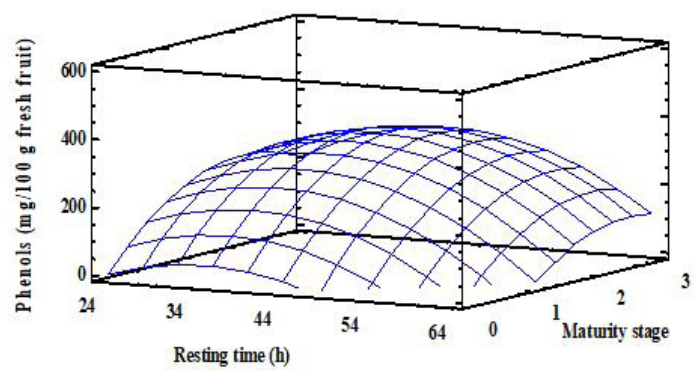

e)

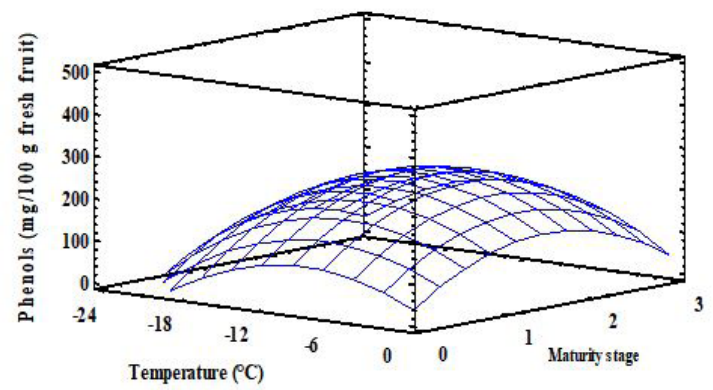

b)

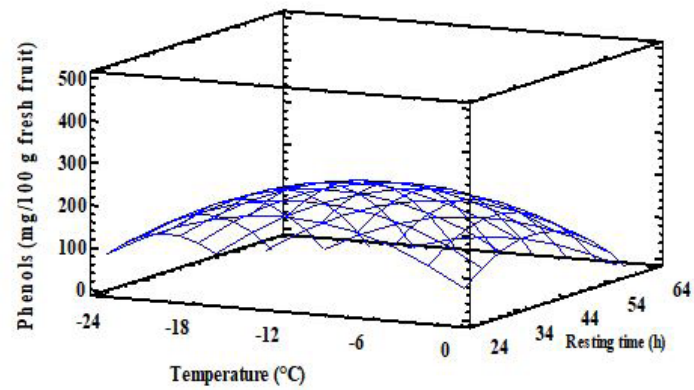

f)

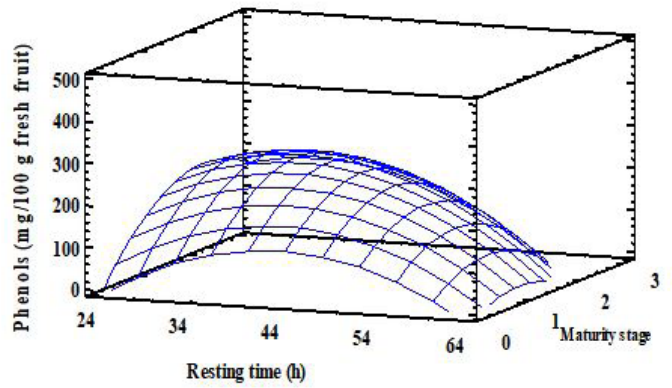

Figure 1. Response surfaces for phenols extracted in strawberry using as fixed variables a) maturity stage: mature; b) Rest time $36 \mathrm{~h} ; \mathrm{c}$ ) Temperature $-10.5^{\circ} \mathrm{C}$, respectively, and blackberry, using as fixed variables d) maturity stage: mature; e) Rest time $36 \mathrm{~h} ; \mathrm{f}$ ) Temperature $-10.5^{\circ} \mathrm{C}$, respectively.

a longer resting time and lower temperature, the extraction of phenols is favoured, since the contact time is prolonged, and the temperature gives stability to the compounds and to the extraction solvent.

The amount of phenolic compounds in blackberries, analysed with the statistical program, indicated that the factors analysed did not have a statistically significant influence within the process, however, when performing the analysis in Table 1, with the condensed results, we can determine that in the case of blackberries, the state of maturity is not significant for the extraction process, since high and similar values are obtained in the three stages of maturity, decreasing the quantity of quantified phenols, which could be explained by the high oxidative metabolism that in this phase favours the appearance of singlet oxygen reactive species. Phenols, as well as ascorbic acid, act as primary antioxidants, producing their decrease, this behaviour coincides with a research conducted by Olaya Zea \&
Restrepo Sánchez (2012), analysing various stages of maturity of different varieties of guava.

As shown in Figure 1a and Figure 2d, with the temperature in conjunction with the resting time, the response increases, moreover, as noted in subsection Figure 1b, 1e and Figure 1c, if the state of maturity has very little influence on the extraction process, since the resting time of $48 \mathrm{~h}$ and temperature of $-18{ }^{\circ} \mathrm{C}$ are the variables that increase the response, ranging from $170 \mathrm{mg}$ to $450 \mathrm{mg}$ of phenols/100 $\mathrm{g}$ of fresh fruit. It is important to note that the most efficient solvent is acetone since the largest amount of phenols was extracted, this is because within the group of phytochemicals contained in blackberry, there are polar compounds which are related to acetone, since as it is a very polar solvent, determining that blackberry has a higher content such as $\rho$-hydroxybenzoic acid and ferulic acid. 

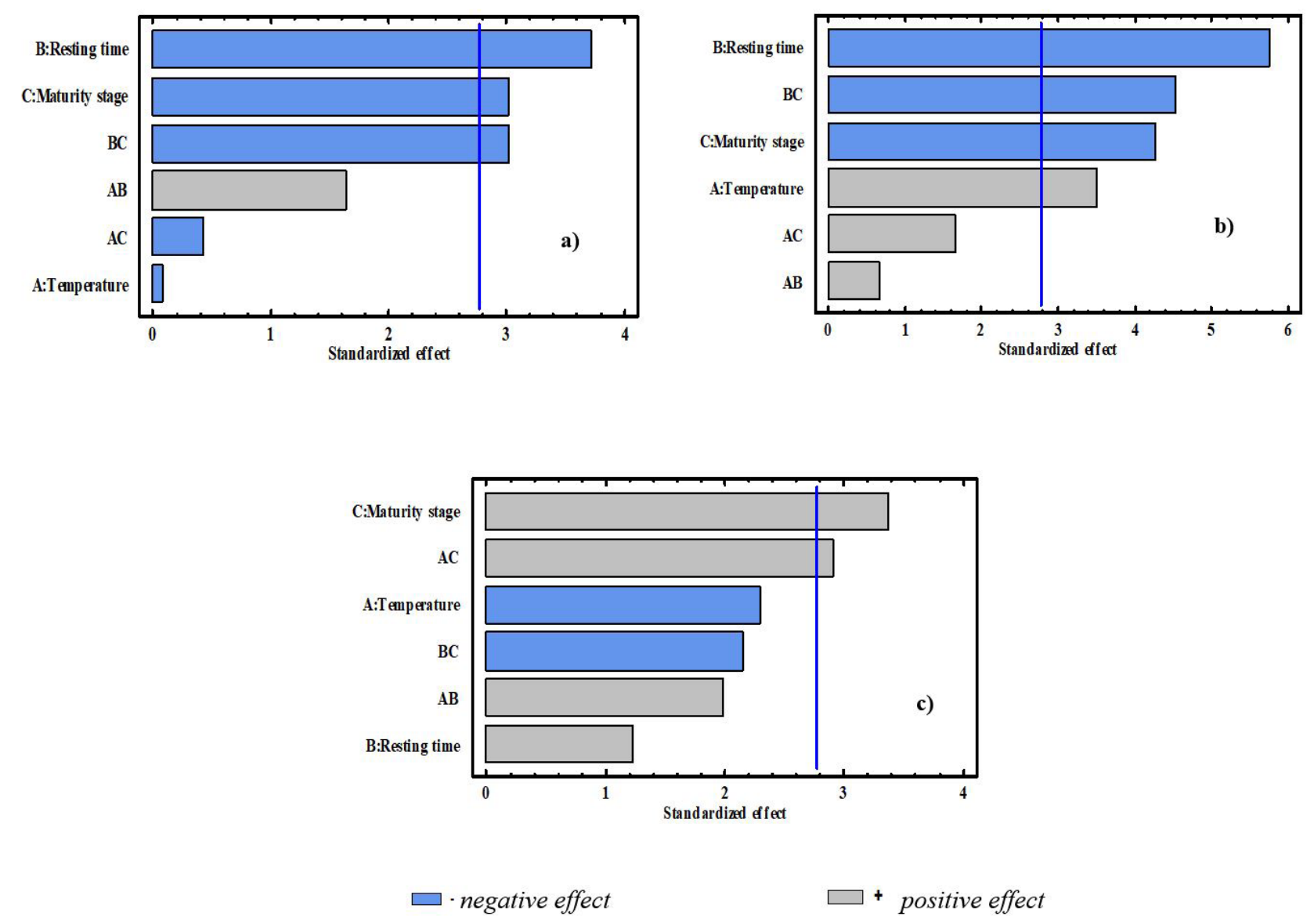

Figure 2. Pareto diagram for antioxidant activity on the $\mathrm{ABTS}^{+}$free radical using different extraction solvents in blackberry: a) acetone; b) ethanol; c) methanol. Extracted from the Statgraphics ${ }^{\circledR}$ program, a statistical analysis of a factorial design was carried out.

\subsection{Total flavonoid content}

Flavonoids are phytochemical compounds related to flavone, found in fruits and vegetables, are soluble in water, and provide pigments to plants. For strawberries, the content of flavonoids extracted was $600.28 \mathrm{mg} / 100 \mathrm{~g}$ of fresh strawberry in over-ripe state to $1,333.27 \mathrm{mg} / 100 \mathrm{~g}$ of fresh strawberry, the largest extraction with acetone, this flavonoid content extracted is not determined by the states of maturity, temperatures or resting times evaluated. It was observed that when using acetone as a solvent the temperature of $-3^{\circ} \mathrm{C}$ favoured the response, as well as the resting time of $24 \mathrm{~h}$ and in the over-mature state. On the other hand, for ethanol a temperature of $-18{ }^{\circ} \mathrm{C}$ is favoured with $48 \mathrm{~h}$ of rest and within the green state, and finally with methanol the temperature does not influence, the resting time of $48 \mathrm{~h}$ and overmatured strawberry do increase the response. When making a comparison with other researches, it was found that strawberry flavonoids were extracted by Aaby et al. (2012), which found 70 to $670 \mathrm{mg} / 100 \mathrm{~g}$ of fresh fruit; Häkkinen et al. (2000), 50 - $140 \mathrm{mg} / 100 \mathrm{~g}$ of fresh fruit; Silva-Espinoza et al. (2013), 120 - 440 mg/100 g of fresh fruit; Kähkönen et al. (2001), $2000 \mathrm{mg} / 100 \mathrm{~g}$ of fresh fruit.

Pigments that were also found in blackberries, for the blackberry values were obtained of $860.16 \mathrm{mg} / \mathrm{g}$ of fresh blackberry to $1,318.03 \mathrm{mg} / 100 \mathrm{~g}$ of fresh blackberry. According to statistical analysis, for acetone, being the solvent with the highest extraction, the temperature does not influence since the amount of flavonoids determined is very similar for both temperatures, while with a resting time of $24 \mathrm{~h}$ and a green-maturity the quantification of flavonoids was greater, on the other hand with ethanol and methanol the behaviour was very similar, the flavonoids quantification was favourable with temperatures of $-18^{\circ} \mathrm{C}$, a resting time of $48 \mathrm{~h}$ and green maturity state, this is because they are solvents with lower polarity so they need to have a longer resting time to have more contact with phenolic compounds and lower temperatures to give more stability to the structures of the flavonoids.

\subsection{Determination of ellagitannins}

The determination of ellagitannins was made in the fresh fruit, the results are expressed in triplicate, the highest amount of ellagitannins were determined in strawberries, with $128.8 \pm 25.19$, $148.01 \pm 24.68,226 \pm 5.40 \mathrm{mg} / 100 \mathrm{~g}$ of fresh fruit, in over-mature, mature stage and green stage, respectively. Aaby et al. (2012) reported $7.7-18.2 \mathrm{mg} / 100 \mathrm{~g}$ of ellagitannins in fresh weight. Häkkinen et al. (2000) quantified $52.2 \mathrm{mg} / 100 \mathrm{~g}$ of fresh fruit; Koponen et al. (2007) determined, 68.3-85.3 mg/100 g; Määttä-Riihinen et al. 
(2004), $224 \mathrm{mg} / 100 \mathrm{~g}$ of fresh fruit; Kähkönen et al. (2001), determined from 1 to $330 \mathrm{mg} / 100 \mathrm{~g}$ in fresh weight, Buendía et al. (2010) from 9.67 to $22.86 \mathrm{mg} / 100 \mathrm{~g}$ of fresh fruit.

The ellagitannins that may be present in strawberries and blackberries are the so-called sanguiin H-6. Kähkönen et al. (2001), in its study it was demonstrated that the fruits of the family Rosaceae, of the genus Rubus and Fragaria, as it is the case of the strawberries and the blackberries, are those that contain greater content of ellagitannins and ellagic acid free.

Bushman et al. (2004) reported the content of ellagitannins in distinct species of blackberry, 30,32 and $21 \mathrm{mg} / 100 \mathrm{~g}$ of fresh fruit. In this investigation, $82.71 \pm 6.56 \mathrm{mg} / 100 \mathrm{~g}$ of fresh blackberries were obtained in green stage, $50.06 \pm 13.12 \mathrm{mg} / 100 \mathrm{~g}$ of fresh blackberries in mature stage and $79.31 \pm 7.17 \mathrm{mg} / 100 \mathrm{~g}$ of fresh blackberries in over-mature stage. Both fruits presented a greater quantity of ellagitannins in green maturity, which is attributed to the fact that some plants accumulate tannins, in this case the ellagitannins, to protect the vulnerable parts of the plant against attack or inactivation by viruses, in addition to that inhibiting the growth of some microorganisms resisting microbial attacks and being recalcitrant to biodegradation, (Field \& Lettinga, 1992).

The amount of ellagitannins that were determined corresponds to 25 to $75 \%$ of the total phenols. The ellagitannins present in the strawberries that were studied, are a fundamental part of the microbicidal activity and antioxidant capacity due to their mechanisms that have been studied in recent years and are explained below:

\subsection{Microbicidal activity}

Ellagic acid and ellagitannins have proven to be potent antimicrobials, experimental work has been carried out against pathogens such as $S$. aureus where it did not allow plasma coagulation in an incubation time of $24 \mathrm{~h}$ at $37^{\circ} \mathrm{C}$, inhibiting the growth of the microorganism (Akiyama et al., 2001). In another study, ellagitannins (Punicalagina), obtained from pomegranate peel (Punica granatum L.), showed antibacterial activity against 18 pathogenic strains of $S$. aureus resistant to penicillin (MRSA), with a minimum inhibitory concentration (MIC) of $61.5 \mu \mathrm{g} / \mathrm{mL}$ (Machado et al., 2002).

\subsection{Antioxidant activity}

Antioxidants are compounds that can delay, inhibit or prevent oxidation of oxidizable compounds, trapping free radicals and decreasing oxidative stress (Ani et al., 2006). The mechanism of ellagic acid and ellagitannins, in particular, is very complicated since they interact in various mechanisms such as: 1 ) reactive free radical oxidation; 2) reactions involving nucleophilic hydroxyl groups; and 3) electrophilic aromatic substitution of its electron-rich aromatic rings (Ahmed et al., 2016; Selva et al., 2017). Ellagitannins in their hydrolyzed form, ellagic acid, can also bind or interact with important biological macromolecules such as DNA, enzymes, and other proteins, as well as smaller substances including minerals (Selva et al., 2017). It was shown that ellagic acid covalently binds to DNA in vitro studies and this has been suggested as a mechanism for its antimutagenic and anticancer activities (Zhang et al., 2014; Selva et al., 2017). Similarly, the interaction of ellagic acid with certain enzymes, such as VEGFR-2 kinase, and $\beta$-glucosidase, can have beneficial effects to prevent and control breast cancer, hyperglycemia and hypertension (Pinto et al., 2010; Zhang et al., 2014; Selva et al., 2017). In vitro studies also showed that ellagic acid shows an effective chelating activity of ferrous ions ( $\mathrm{Fe})$, which contributes to its antioxidant properties (Kilic et al., 2014), and binds to human serum albumin, the main transport protein in blood serum (Pattanayak et al., 2017).

\subsection{Determination of antioxidant activity}

The results of the antioxidant activity indicate that the strawberry extracts could trap the $\mathrm{DPPH}$ and $\mathrm{ABTS}^{+}$radicals, regardless of the state of maturity, the resting time or the temperature, for $\mathrm{ABTS}^{+}$there was $84-94 \%$ inhibition, and for DPPH $80-97 \%$ inhibition. For blackberry, the percentage of inhibition reported for DPPH was $76-86 \%$, and for $\mathrm{ABTS}^{+} 88-92 \%$. For DPPH, the factors evaluated in the extraction process had no influence on the antioxidant activity, however, statistically for $\mathrm{ABTS}^{+}$, according to the Analysis of Variance (ANOVA), the resting time for the solvent acetone and ethanol with a level of $95 \%$ confidence, is the variable that most influences the antioxidant activity, in addition, the state of maturity and the interaction of time of rest and state of maturity, are the statistically significant factors, as observed in the Pareto diagram in Figure 2.

For the solvent methanol, in Figure 2c, the state of maturity, the temperature, as well as the interaction between both, statistically are the most influential during the process, the state of maturity where the highest antioxidant activity was obtained is in its overmature state, and with a temperature of $-18^{\circ} \mathrm{C}$. The compounds that are being measured by the $\mathrm{ABTS}^{+}$ technique is hydrophilic and lipophilic in nature.

\subsection{Microbicidal activity}

The microbicidal activity for gram-positive bacteria was evaluated on a lawn of $S$. aureus, and for gram-negative bacteria on E. coli, where 10 different antibiotics were used, as well as the extracts of strawberries and blackberries. All the extracts inhibited the growth of the microorganisms evaluated, haloes of $S$. aureus inhibition were obtained from 7 to $11 \mathrm{~mm}$ with acetone solvent, from 7.5 to $20.5 \mathrm{~mm}$ with ethanol and from 7.5 to $16 \mathrm{~mm}$ with methanol when using strawberries; on the other hand, for blackberries, haloes of 10 to $25.5 \mathrm{~mm}$ were obtained with acetone, $8.75 \mathrm{~mm}$ to $21 \mathrm{~mm}$ with ethanol, 7.5 to $15.5 \mathrm{~mm}$ with methanol.

For E. coli, halos of 8.5 to $18.5 \mathrm{~mm}$ were presented for acetone, from 8 to $21 \mathrm{~mm}$ for ethanol, from 8 to $14 \mathrm{~mm}$, using strawberries. Using blackberries, the size of the haloes reported, comprised 10.5 to $16.5 \mathrm{~mm}$ with acetone solvent, 7 to $24.5 \mathrm{~mm}$ ethanol and 7 to $16.5 \mathrm{~mm}$ for methanol. The activity of the extracts is considered bactericidal. For both microorganisms, the best halos of inhibition were presented in the extracts whose solvent was ethanol, using blackberries as a source of phytochemicals, in addition, the generated halo surpassed antibiotics such as ciprofloxacin $5 \mathrm{mcg}$, ampicillin $10 \mathrm{mcg}$, and nitrofurantoin 
Table 2. Antimicrobial activity (diameter of the inhibition zone, $\mathrm{mm}$ ) of extracts with acetone solvent, ethanol, methanol, using the inhibition halo technique. The data are expressed as the mean \pm standard deviation, $\mathrm{n}=3$.

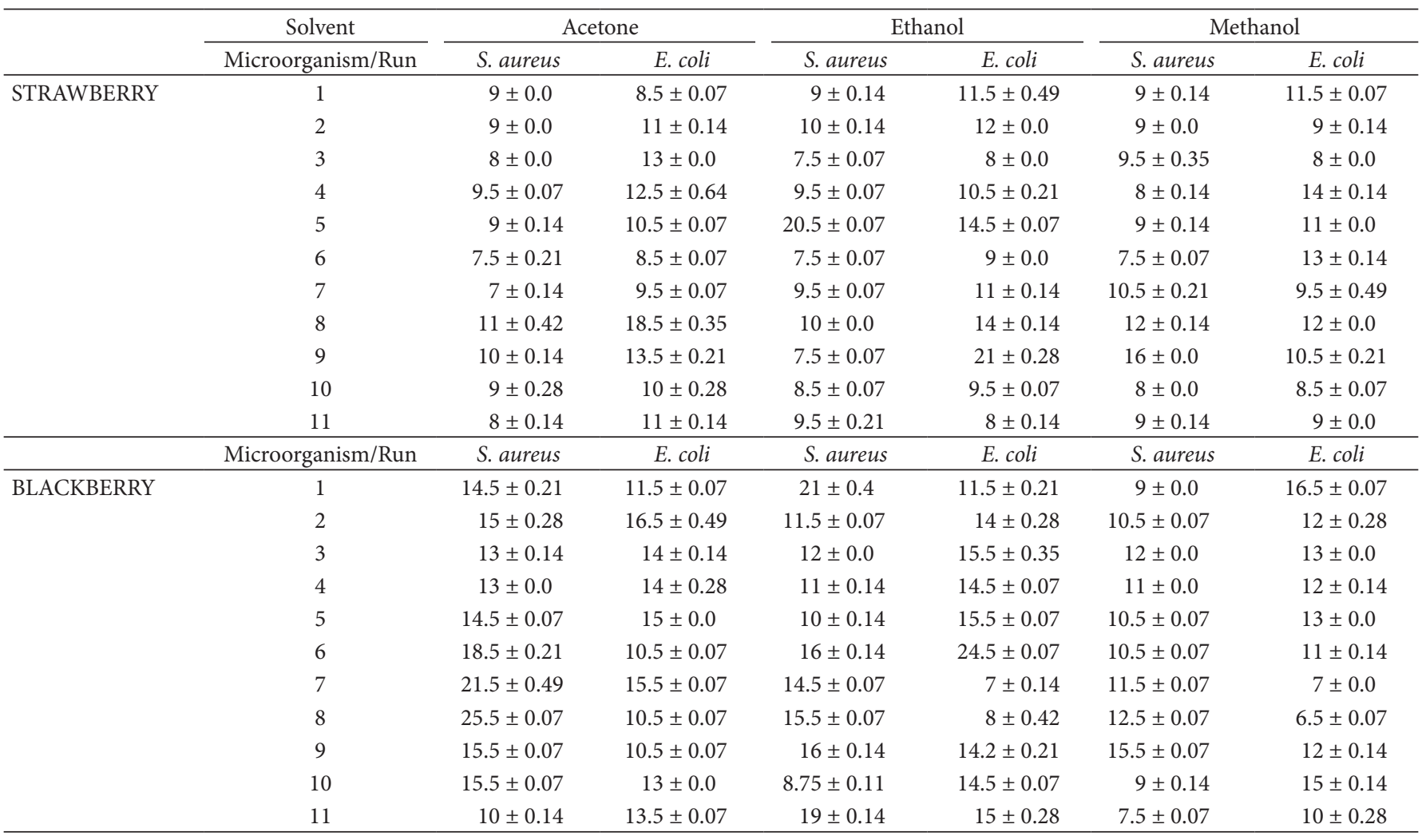

$300 \mathrm{mcg}$ for both fruits. Strawberry extracts that inhibited the growth of $S$. aureus, had a halo of inhibition that exceeded broad-spectrum antibiotics such as: $10 \mathrm{mcg}$ penicillin, $30 \mathrm{mcg}$ cephalothin, $1 \mathrm{mcg}$ dicloxacin, and low-ampicillin $10 \mathrm{mcg}$ halo. On the other hand, the extracts obtained from blackberry presented a halo of inhibition greater than penicillin $10 \mathrm{mcg}$, dicloxacin $1 \mathrm{mcg}$, and ampicillin $10 \mathrm{mcg}$.

Three controls were used, two negatives which are distilled water and the solvent like as ethanol, methane or acetone, as appropriate in the experiment. The third control that was used was the positive control that was the antibiotic. Three replicates of each run were made with each solvent. The results are show in the Table 2.

Reyes Pillajo (2017) carried out a study in red fruits where he obtained inhibition halos from 6 to $19 \mathrm{~mm}$, as we can see the haloes we obtained are within this range and some exceed $19 \mathrm{~mm}$, this is attributed to the different substances present in red fruits (blueberry, mortiño, capulí, strawberries, blackberries, among others) such as flavonoids, flavones, isoflavones, these compounds have defence functions in the plant, such as antimicrobial agents, protection against herbivores, UV radiation.

\section{Conclusions}

The search for alternatives to obtain new compounds that may be beneficial for health, has been directed to be carried out in plant sources, which has given the possibility of studying the endemic fruits of the region, highlighting strawberries and the blackberries, giving them an added value. One of the important aspects of this research is to present results that can support the composition of fruits, mainly referring to the phytochemical compounds, which have bactericidal activity against microorganisms such as E. coli and S. aureus, as well as antioxidant activity being able to trap the free radicals of $\mathrm{ABTS}^{+}$ and DPPH. In addition, of these important properties mentioned, the amount of phenols and total flavonoids was determined, finding that the solvent that obtained the highest extraction was acetone, concluding that the extraction carried out contains polar compounds. On the other hand, it was possible to determine ellagitannins, found mainly in strawberries, remembering the importance of ellagitannins, which can be used in subsequent processes to produce ellagic acid.

\section{Acknowledgements}

We thank the partial donations to the Project Evaluación de la actividad enzimática de levaduras no-convencionales para la producción de ácido elágico", Convocatoria de Apoyo a Proyectos de Investigación Científica, Aplicada, Desarrollo Tecnológico e Innovación 2017-2, Tecnológico Nacional de México (6268.17-P).

\section{References}

Aaby, K., Mazur, S., Nes, A., \& Skrede, G. (2012). Phenolic compounds in strawberry (Fragaria x ananassa Duch.) fruits: Composition in 27 cultivars and changes during ripening. Food Chemistry, 132(1), 86-97. http://dx.doi.org/10.1016/j.foodchem.2011.10.037. PMid:26434267. 
Ahmed, T., Setzer, W. N., Nabavi, S. F., Orhan, I. E., Braidy, N., SobarzoSanchez, E., \& Nabavi, S. M. (2016). Insights into effects of ellagic acid on the nervous system: a mini review. Current Pharmaceutical Design, 22(10), 1350-1360. http://dx.doi.org/10.2174/13816128226 66160125114503. PMid:26806345.

Akiyama, H., Fujii, K., Yamasaki, O., Oono, T., \& Iwatsuki, K. (2001). Antibacterial action of several tannins against Staphylococcus aureus. The Journal of Antimicrobial Chemotherapy, 48(4), 487-491. http:// dx.doi.org/10.1093/jac/48.4.487. PMid:11581226.

Andrade Esquivel E, Morales Guzmán J, Ortiz Calderón AL, Rodríguez García M V, Ronquillo Vázquez A, Sánchez Serrano AC, Rodríguez Damián AR, Guzmán SH. (2008). Análisis de las propiedades fisicoquímicas de la Zarzamora en variedades Brazos, Cherokee y Tupy de la zona alta de Michoacan. Retrieved from http://respyn2. uanl.mx/especiales/2008/ee-08-008/documentos/A027.pdf

Ani, V., Varadaraj, M. C., \& Naidu, K. A. (2006). Antioxidant and antibacterial activities of polyphenolic compounds from bitter cumin (Cuminum nigrum L.). European Food Research and Technology, 224(1), 109-115. http://dx.doi.org/10.1007/s00217-006-0295-z.

Arellano Gómez, L., Saucedo Veloz, C., \& Arévalo Galarza, L. (2005). Cambios bioquímicos y fisiológicos durante la maduración de frutos de zapote negro (Diospyros digyna Jacq.). Agrociencia, 39(2), 173-181.

Batra, A., \& Saxena, R. K. (2005). Potential tannase producers from the genera Aspergillus and Penicillium. Process Biochemistry, 40(5), 1553-1557. http://dx.doi.org/10.1016/j.procbio.2004.03.003.

Brand-Williams, W., Cuvelier, M. E., \& Berset, C. (1995). Use of a free radical method to evaluate antioxidant activity. Food Science and Technology, 28(1), 25-30.

Buendía, B., Gil, M. I., Tudela, J. A., Gady, A. L., Medina, J. J., Soria, C., López, J. M., \& Tomás-Barberán, F. A. (2010). HPLC-MS analysis of proanthocyanidin oligomers and other phenolics in 15 strawberry cultivars. Journal of Agricultural and Food Chemistry, 58(7), 39163926. http://dx.doi.org/10.1021/jf9030597. PMid:20038100.

Bushman, B. S., Phillips, B., Isbell, T., Ou, B., Crane, J., \& Knapp, S. (2004). Chemical composition of cranberry (Rubus spp.) seeds and oils and their antioxidant potential. Journal of Agricultural and Food Chemistry, 52(26), 7982-7987. http://dx.doi.org/10.1021/jf049149a. PMid:15612785.

Field, J. A., \& Lettinga, G. (1992). Toxicity of tannic compounds to microorganisms. In R. W. Hemingway \& P. E. Laks (Eds.), Plant polyphenols (pp. 673-692). Boston: Springer. http://dx.doi. org/10.1007/978-1-4615-3476-1_39.

Finn, C. E., Kempler, C., Moore, P. P., Strik, B. C., Yorgey, B. M., Martin, R. R., \& Galletta, G. J. (2011). "Sweet Bliss" strawberry. HortScience, 46(12), 1701-1705. http://dx.doi.org/10.21273/HORTSCI.46.12.1701.

Fonseca-García, L., Calderón-Jaimes, L., \& Rivera, M. (2014). Capacidad antioxidante y contenido de fenoles totales en café y subproductos del café producido y comercializado en norte de Santander (Colombia). Vitae, 21(3), 228-236.

Häkkinen, S. H., Kärenlampi, S. O., Mykkänen, H. M., Heinonen, I. M., \& Törrönen, A. R. (2000). Ellagic acid content in berries: Influence of domestic processing and storage. European Food Research and Technology, 212(1), 75-80. http://dx.doi.org/10.1007/s002170000184.

Huang, W., Niu, H., Li, Z., He, Y., Gong, W., \& Gong, G. (2008). Optimization of ellagic acid production from ellagitannins by coculture and correlation between its yield and activities of relevant enzymes. Bioresource Technology, 99(4), 769-775. http://dx.doi. org/10.1016/j.biortech.2007.01.032. PMid:17363241.

Kähkönen, M. P., Hopia, A. I., \& Heinonen, M. (2001). Berry phenolics and their antioxidant activity. Journal of Agricultural and Food
Chemistry, 49(8), 4076-4082. http://dx.doi.org/10.1021/jf010152t. PMid:11513713.

Kays, S. (1997). Postharvest physiology of perishable plant products (1st ed.). Athens: Exon Press.

Kilic, I., Yeşiloğlu, Y., \& Bayrak, Y. (2014). Spectroscopic studies on the antioxidant activity of ellagic acid. Spectrochimica Acta. Part A, Molecular and biomolecular spectroscopy, 130, 447-452. http:// dx.doi.org/10.1016/j.saa.2014.04.052. PMid:24813273.

Koponen, J. M., Happonen, A. M., Mattila, P. H., \& Törrönen, A. R. (2007). Contents of anthocyanins and ellagitannins in selected foods consumed in Finland. Journal of Agricultural and Food Chemistry, 55(4), 1612-1619. http://dx.doi.org/10.1021/jf062897a. PMid:17261015.

Lei, Z., Jervis, J., \& Helm, R. F. (2001). Use of methanolysis for the determination of total ellagic and gallic acid contents of wood and food products. Journal of Agricultural and Food Chemistry, 49(3), 1165-1168. http://dx.doi.org/10.1021/jf000974a. PMid:11312829.

Liu, P., Kallio, H., \& Yang, B. (2011). Phenolic compounds in hawthorn (Crataegus grayana) fruits and leaves and changes during fruits ripening. Journal of Agricultural and Food Chemistry, 59(20), 11141-11149. http://dx.doi.org/10.1021/jf202465u. PMid:21905654.

Määttä-Riihinen, K. R., Kamal-Eldin, A., \& Törrönen, A. R. (2004). Identification and Quantification of Phenolics Compounds of Fragaria and Rubus species (Family Rosaseae). Journal of Agricultural and Food Chemistry Society, 13(5), 6178-6187. http://dx.doi.org/10.1021/ jf049450r.

Machado, T. B., Leal, I. C. R., Amaral, A. C. F., Santos, K. R. N., Silva, M. G., \& Kuster, R. M. (2002). Antimicrobial ellagitannin of Punica granatum fruits. Journal of the Brazilian Chemical Society, 13(5), 606-610. http://dx.doi.org/10.1590/S0103-50532002000500010.

Márquez-López, A., Ramírez-Conejo, J. D., Chávez-Madrigal, R., ChávezParga, M. C., \& González-Hernández, J. C. (2019). Production of ellagic acid by mixed consortium of unconventional yeasts (In press).

Martínez-Soto, G., Mercado-Flores, J., López-Orozco, M., \& PrietoVelásquez, B. (2008). Propiedades fisicoquímicas de seis variedades de fresa (Fragaria ananassa) que se cultivan en Guanajuato. Revista Salud Pública y Nutrición, 8(1), 1-11.

Middleton, E. Jr, Kandaswami, C., \& Theoharides, T. C. (2000). The effects of plant flavonoids on mammalian cells: implications for inflammation, heart disease, and cancer. Pharmacological Reviews, 52(4), 673-751. PMid:11121513.

Novoa, R. H., Bojacá, M., Galvis, J. A., \& Fischer, G. (2006). La madurez del fruto y el secado del cáliz influyen en el comportamiento poscosecha de la uchuva, almacenada a $12{ }^{\circ} \mathrm{C}$ (Physalis peruviana L.). Agronomia Colombiana, 24(1), 77-86.

Olaya Zea, J. A., \& Restrepo Sánchez, L. P. (2012). Estudio del contenido de fenoles y actividad antioxidante de guayaba en diferentes estados de madurez. Acta Biologica Colombiana, 17(3), 611-624.

Pattanayak, R., Basak, P., Sen, S., \& Bhattacharyya, M. (2017). An insight to the binding of ellagic acid with human serum albumin using spectroscopic and isothermal calorimetry studies. Biochemistry and Biophysics Reports, 10, 88-93. http://dx.doi.org/10.1016/j. bbrep.2017.03.001. PMid:29114572.

Pinto, M. S., de Carvalho, J. E., Lajolo, F. M., Genovese, M. I., \& Shetty, K. (2010). Evaluation of antiproliferative, anti-type 2 diabetes, and antihypertension potentials of ellagitannins from strawberries (Fragaria ananassa Duch) using in vitro models. Journal of Medicinal Food, 13(5), 1027-1035. http://dx.doi.org/10.1089/jmf.2009.0257. PMid:20626254.

Reyes Pillajo, I. Y. (2017). Evaluación de la cantidad antioxidante y antibacteriano de los frutos rojos sobre cepas de Streptococcus Mutans: 
estudio in vitro (Proyecto de investigación presentado como requisito previo a la obtención del título de Odontóloga). Quito: Carrera de Odontologia.

Seeram, N., Lee, R., Hardy, M., \& Heber, D. (2005). Rapid large-scale purification of ellagitannins from pomegranate husk, a by-product of the commercial juice industry. Separation and Purification Technology, 41(1), 49-55. http://dx.doi.org/10.1016/j.seppur.2004.04.003.

Selva, M., Carole, T., John, S., Xingqian, Y., Xue, S. J. (2017). Ellagic acid in strawberry (Fragaria spp.): Biological, technological, stability, and human health aspects. Food Quality and Safety, 1(1), 227-252.

Silva-Espinoza, B., Ortega-Ramírez, L., González-Aguilar, G., Olivas, I., \& Ayala-Zavala, J. (2013). Protección antifúngica y enriquecimiento antioxidante de Fresa con aceite esencial de hoja de canela. Revista Fitotecnia Mexicana, 36(3), 217-224.
Valencia Sullca, C. E., \& Guevara Pérez, A. (2013). Elaboración de néctar de zarzamora (Rubus fructicosus L.). Scientia Agropecuaria, 4(2), 101-109. http://dx.doi.org/10.17268/sci.agropecu.2013.02.03.

Vázquez-Flores, A., Álvarez-Parrilla, E., López-Díaz, J., \& WallMedrano, A. (2012). Hydrolyzable and condensed tannins: chemistry, advantages and disadvantages of their intake. Tecnociencia Chihuahua, 5(2), 84-94.

Wilson, T. C., \& Hagerman, A. E. (1990). Quantitative determination of ellagic acid. Journal of Agricultural and Food Chemistry, 38(8), 1678-1683. http://dx.doi.org/10.1021/jf00098a011.

Zhang, H. M., Zhao, L., Li, H., Xu, H., Chen, W. W., \& Tao, L. (2014). Research progress on the anticarcinogenic actions and mechanisms of ellagic acid. Cancer Biology \& Medicine, 11(2), 92-100. PMid:25009751. 